\title{
1. The rise of regional infrastructure systems
}

The rise of regionalism has been a major trend in the international political economy (IPE) during the post-Second World War era. Accompanying the maturing of this phenomenon, and as a result of other parallel processes, regional infrastructure systems (RIS) have emerged. These RIS have arisen from the increased interaction between national infrastructure systems (NIS) across mainly contiguous territories and are enabled by the systemic interoperability and physical interconnection between the systems. The development of these regional systems has been compounded by ease of user access to the constituent NIS, enabling trans-national relations to be formed which, in turn, further legitimise RIS establishment and evolution. As such, RIS are not stand-alone entities but composite systems derived from the interconnection and integration of state-based systems. This reflects the position taken throughout this book that states remain the primary drivers of the development of RIS and are driven by a need to secure and enhance their territoriality within an internationalising economic system. The advocacy of state primacy positions this work within a broad neo-realist framework, but it must also be recognised that, although the state might be the dominant actor in the development and evolution of RIS, it is not the only actor.

This chapter builds on the themes in the above paragraph and explores more fully the core characteristics and drivers of RIS as a prelude to the specific regional chapters that make up the majority of this work. Initially, this focuses on identifying the form and nature of infrastructure. Thereafter, the link between states and infrastructuring is explored, largely through the prism of territoriality. Finally, the chapter links these themes with regionalism and explores the main drivers and motivations for the development of RIS.

\section{THE INFRASTRUCTURAL FORM}

Infrastructure is an increasingly amorphous concept with its definition varying with the nature of the role for which it is designed. Such 
ambiguities are driven by the flexible and evolving nature of the systems which infrastructures are designed to support. Most conventional definitions focus on infrastructure's physical manifestations (see Neuman, 2006 for a review). In this approach, infrastructures are those physical structures that are embedded within socio-economic systems that enable these systems to operate effectively. Such definitions often refer to the interconnected nature of infrastructure to the extent that they operate as a single network (that is, as a system of infrastructures - see below). The focus on the network as the core unit of analysis stresses that the role of infrastructure is to facilitate and channel flows through the establishment of the necessary supporting physical links and hubs (to store, redirect or process flows) within and across the space where the network has reach (Edwards et al., 2009). Such definitions lead inevitably to the equating of infrastructure with economic infrastructure: that is, those interconnected physical assets that enable and support the economic system and include energy, transport and information networks (Organisation for Economic Co-operation and Development 2008). In this volume, it is these networked economic infrastructures that form the bedrock of the analysis as they have the strongest regional dimensions.

However, although these economic infrastructures are undoubtedly at the core of conventional understanding of what comprises infrastructure, there is also a growing awareness that systemic approaches to infrastructure need this definition to be extended to soft infrastructure. Soft infrastructure represents - as defined here - the institutions required to maintain and upgrade physical infrastructure including rules of use, interoperability standards, legal systems, financing, etc. The increased focus on soft infrastructure highlights how hard infrastructure depends on social, legal and institutional systems for their operation and territorial efficacy (Markard, 2011). It also underlines how important users are to the sustainability of the system through their adherence to rules of usage, education in effective and improper usage and how their general behaviour in the utilisation of physical infrastructure is central to its effectiveness (Edwards et al., 2009). As will be highlighted throughout this volume, soft infrastructure has become a salient factor in the interconnecting of national systems that lie at the core of many RIS strategies.

According to La Porte (1996), networked infrastructures are characterised by a number of features which underscore their systemic nature. ${ }^{1}$ First, these infrastructures are 'tightly coupled', meaning - in practical

1 This systemic treatment underscores that a network of infrastructures is more than simply the sum of its parts. 
terms - that they are covered by a number of rules regarding their operation and usage which, if not adhered to, can either lower the benefits of the system or create harm within it. This is most evident within the notion of functional complexity created by the cyber systems noted below. Second, network effects are a powerful factor driving the extensiveness and socio-economic penetration of infrastructure (Jackson et al., 2007). This suggests an in-built dynamic in network extension as the more users and/or greater reach of a network, the higher the value that users obtain from, and attach to, it. The higher the value those users obtain from a network, the more it creates an internal dynamic towards expansion and structural complexity (see below). Third, these systems offer public services that cannot usually be offered through any other channel. This can result from issues of natural monopoly and also from the imperatives of social and economic cohesion. Fourth, these infrastructures are the source of public concern when they fail (Starr and Ruhleder, 1996). This is also reflected within a fifth (and final) characteristic; namely, that infrastructures are a source of apprehension arising from the legacy of operating failures (Zimmerman, 2001). The consequence of this anxiety is that public bodies need to constantly monitor and assess the performance of these systems which are core to state territoriality (see below).

This systemic approach to infrastructures has found currency in the literature where a consensus has formed around the treatment of infrastructures as complex systems operating not as a single entity but as a composite of interacting components (for a review, see Rinaldi et al., 2001). Hughes (1987) arguably led the field in such approaches, claiming that infrastructures need to be positioned as large technical systems that exhibit momentum towards perpetual growth, with each progression in their evolution adding extra complexity. However, increasing complexity can come up against bottlenecks or reverse salients given that change within a system can create new conflicts between its component parts. Despite such caveats, it is useful to delineate infrastructural complexity in the following two basic forms.

1) Functional complexity: this is a reflection of the phenomenon that infrastructure often has other infrastructure embedded within it which creates the simultaneous usage of infrastructures at any single point in time or place. This can give rise to the three types of interdependence identified by Rinaldi et al. (2001): physical interdependence (where the state of one infrastructure depends on the outputs of another); cyber interdependence (the dependence of a 
given infrastructure system on embedded information infrastructure); and logical interdependence (where the condition of one infrastructure depends on the state of another through a link that is not directly physical (such as through soft infrastructure).

2) Spatial complexity: these are interdependencies within infrastructure systems created by events and/or processes within one piece of infrastructure and/or infrastructure system that impact on the effective operation of another where the two are not co-located. This implies no assumptions about the degree of physical separation between infrastructures nor can the lag effects of impact be predicted: they can be significant within energy and transport systems but almost immediate in the case of information infrastructure. The impact also depends on the options for alternative routes to militate against such failures (see Johnson and Turner, 2017).

At the core of this functional and spatial complexity is the conception of infrastructure systems as a more distributed set of activities comprising technical, social and institutional factors, reflecting the reality that infrastructure is not formed from a simple act of being but from the relationships formed between users. The ability of infrastructure to build and sustain relations gives evident support to Neuman's (2006) position that infrastructure is empowering. Infrastructure transforms relations between users into something that has greater capacity, enabling these relations to be further expanded and transformed. This transformative capacity reflects how flows between users and the value created by phenomena such as network effects can have a broad impact on socioeconomic systems. Starr and Bowker (2006) see user groups as central to this process as they generate learning as a 'community of practice' which stimulates proper usage and engagement between users.

However, Starr and Bowker (1995) argue that such a relational treatment of infrastructure has to acknowledge that any piece of infrastructure only becomes and operates as infrastructure at the point in time and/or place of usage and that the usefulness of infrastructure varies across different socio-economic groups. This means that, by establishing universal and ubiquitous infrastructure, the state (as the primary infrastructuring agent - see below) has to build infrastructure that will not be used by all and may be underused or offer limited advantages to some segments of the population. Thus, as a relational system, infrastructure is characterised - for any given user - by intermittent usage but which is accessible on demand. Moreover, Starr and Bowker (1995) argue that because usage is often an implicit act, infrastructure relations are embedded within socio-economic and technological structures to the 
extent that the infrastructure is often hidden in many of the tasks they perform and support. This is especially so when infrastructures operate and interoperate through standardised interfaces which blur or render invisible the demarcation between different infrastructures. The legacy of this embeddedness results in a tendency to understate and misunderstand the level of infrastructural complexity and its impacts at any given point in time and/or space. As a result of this embedded complexity, infrastructure only becomes visible when it breaks (i.e. when its stops acting as infrastructure).

\section{THE ROLE OF INFRASTRUCTURING}

The notion of infrastructuring reflects the idea that there is a need to organise space through the provision of the necessary physical structures. It is through these structures that territoriality is realised by enabling the maintenance of the central relations between the state and civic society (Brenner, 1999b). Embedded within the logic of infrastructuring is what van der Vleuten (2004) terms the 'ideology of circulation', which suggests that socio-economic systems prosper through their ability to facilitate and secure resource circulation. For states, this ideology represents a powerful metaphor for the process of infrastructuring as territoriality requires such circulation to secure relations and its territorial space (Krüger, 1969). However, as the ideology of circulation is primarily focused on economic systems, it can be criticised for its limited approach. Hugill (1995) notes that polities engage in infrastructuring for reasons of political control, stressing that the importance of infrastructure systems lies not only in their existence but in how they are used. This is also evident in the literature on large technical systems (Hughes, 1983), which developed the idea that infrastructures are of strong social as well as economic significance. Van der Vleuten (2004) sees these narratives as potentially contradictory. However, the rationality of state territoriality does offer a unifying framework. As Mann (1984) identified, a state is defined by its socio-economic configuration which, in turn, is shaped by its territoriality and centrality. The state radiates its resources from its centre but will stop (in most cases) at the defined territorial borders.

At the core of understanding the state-infrastructure nexus is the fact that states strategise. Such strategies are long-term efforts made by the state to sustain its territoriality (defined here as "the behaviour that uses a bounded space, a territory, as the instrument for securing a particular outcome' (Taylor, 1995, p. 151)). Some authors find direct parallel in such territorial strategies with their corporate equivalent (for example, 
Auster and Silver, 1979; Stopford et al., 1991) as states position themselves in an increasingly competitive system (Palan et al., 1996). Whilst such contributions are valid, they tend to be one dimensional, stressing the logic that the state sustains its territoriality through improvements in the economic wellbeing of its citizens. Much of this analysis focuses on growth as a source of welfare of a state's population. However, a population's welfare also depends on security and socioeconomic cohesion. Moreover, in addition to these positive strategic drivers, there are also negative forces that propel state action, namely (as mentioned below) those strategies based on attaining territorial control. Thus, infrastructuring emerges out of the strategies developed and deployed by states to assert and sustain their territoriality. It is, as Brenner (1999b) noted, a means through which the state turns space into territory to serve its own ends and to meet the needs of itself and of the population within its borders.

State strategies to enable and sustain territoriality are supported through the process of infrastructuring which seeks not merely to facilitate usage to build relations that enable the infrastructural mandate (see below), but also to set the terms of usage, limits and controls and outlaws or deters those that are contrary to this objective. This pattern suggests infrastructural relations are dynamic and reflect the learning processes within communities surrounding and utilising these systems as technologies and user groups change (Starr and Ruhleder, 1996; Starr and Bowker, 1995). However, using relational systems as a means of attaining territoriality has been made more complex through what Graham and Marvin (2001) term the 'splintering' of user demands: that is, not only do infrastructural relations vary between users over space and time (Starr and Bowker, 2006), but also within and between communities/user groups. Users will focus on those infrastructures they need as part of their membership of communities and their immediate or semi-immediate functioning (Frischmann, 2012). The centrality of the state to the infrastructuring process stands alongside the conventional market failure logic that is often used to justify state-based involvement in infrastructure provision and management (Schneider and Jäger, 2003). Whilst market failure has to some degree been militated through new models of infrastructure management (such as those informed by contestable market theory), this has also been compounded by clarity over regulation that allows pre-competitive agreement between the modular components of infrastructure to militate giant fragmented systems. However, the territorial themes remain consistent.

Howe et al. (2015) argue that infrastructure systems have within them a number of paradoxes which, by implication, will shape their impact on 
state territoriality. The first is that whilst infrastructure is generative (that is, it enables flows) it also degenerates and - as it is often taken for granted - reinfrastructuring is often neglected. Second, as much as infrastructure reflects path dependencies, it has also to reflect changing trends and contexts. This manifests itself in the retrofitting of infrastructure in response to unanticipated flows and technological/economic developments. However, these infrastructure systems (due to path dependencies) are often difficult to adapt, leading to a diminishing of their ability to serve the purpose for which they were designed. Third, as much as infrastructures are used to mitigate risk, they also introduce new risks into socio-economic and political systems, especially as their complexity grows. Such narratives are partially reflected in how the complexity of infrastructure creates a number of challenges for the sustained operation of the NIS as a support to state territoriality. The main challenges as identified by Johnson and Turner (2017) are:

1) Obsolescence: where infrastructure is no longer relevant to the needs of the state as the infrastructure becomes divorced from its shifting context (that is, economic growth and development, productivity, climate change and environment, population and demography and technology, etc.).

2) Senescence: the erosion and degradation of infrastructure as a result of the ageing process. Systems are often too slow to change. Consequently, infrastructure begins to fail more often and with greater disruptive effects.

3) Complexity catastrophe (Kauffman, 1996): this occurs where infrastructure and its interlinkages grow so complex that they can fail in a multitude of ways, many of which are not readily evident at the point of construction and/or usage. This can often stem from the fact that systems can change rapidly, creating new interconnections without full comprehension of the risks created by such complexity.

4) Failing soft infrastructure: this is reflective of the inability of the supporting institutional systems to stimulate NIS adaptation through strong state-infrastructure owner ties; limits to modular-driven innovation and systemic liberalisation; absence of enforcement of appropriate regulation; failure to build user groups; etc.

5) Failing nodes (McKelvey, 2002): this is based on connectivity failure where human failure generates a loss of capability and an inadequate coverage to sustain the system. This can be created by the absence, failure and obsolescence of social infrastructure which is central to creating institutional capability. 


\section{INFRASTRUCTURING AND THE NATIONAL INFRASTRUCTURE SYSTEM}

The role of infrastructuring as a territorial strategy is to secure and promote the development of the NIS where the NIS is the totality of networked infrastructure located within the borders of a state. The salience of the NIS emanates from its 'infrastructural mandate' which is based on the requirement for a NIS to support state-centred territoriality, thereby enabling the state to establish and sustain its relationships with civil society and business that facilitate its sovereignty over a demarcated space (Brenner, 1999a). Using a multi-disciplinary approach, Johnson and Turner (2017) maintain that the relationship between the state and the NIS can be synthesised into the four interrelated processes of the infrastructural mandate: control, integration, security and growth/ development. This approach - which will be followed here - reflects a neo-Weberian perspective of the state, namely that the state is a social body/social organisation that pursues specific goals through the provision of structures that enable it to enhance the welfare of its population (Palan et al., 1996). The components of the infrastructural mandate are examined in more detail below.

\section{Control}

Mann (1984) argues that only those spaces that are covered by spatially extensive and intensively used infrastructures can be regarded as territory. More explicitly, Mann refers to the importance of infrastructural power to states as a means of enabling them to penetrate civil society and to facilitate power relations between the state and all the agents within a territory (Brenner, 1999a; Elden, 2010, 2013). As such, infrastructure can operate as a channel for social regulation through which the state acquires the capacity to assert power over other users within a territory. The efficacy of such capacity is a reflection of the state's ability to generate and move resources (both tangible and intangible) around a territory. As Mann (1997) notes, it is through such channels that ideological, economic, military and political power are exercised and state failure is often accompanied by the loss of control or erosion of this infrastructural power (Eriksen, 2011; Brenner and Elden, 2009). In this context, infrastructure is not always a positive force as it can provide channels through which structural violence (see below), repression and internal dissent can occur. 
For the realisation of infrastructural power, states have often conventionally felt the need to control infrastructure (especially communications systems) via direct ownership. However, the rise of neo-liberalism has challenged this convention as ownership of key infrastructures has frequently switched to non-state actors. To some (such as Strange, 1996), this represents the retreat of the state; to others it is a pragmatic strategy to upgrade the NIS when the state is financially constrained (Schneider and Jäger, 2003). However, the emergence of such polycentric systems (Turner, 2017) is only realised through state sanction given that the state maintains its influence through conditions of ownership, regulation, direct finance and other methods. In short, even though the state may not own these systems, it can still steer owners and users towards specific aims that support its territorial objectives (Braithwaite and Drahos, 2000; Moran, 2003). In policy and state strategy terms, the most salient expression of this has been the rise of critical infrastructure strategies (Brown, 2006).

Control through the NIS depends on infrastructural relations by users becoming dependent on that infrastructure system for social, economic and political functioning. This control is realised through both formal and informal methods, such as the shaping of social, cultural and personal norms, which influence the form and intensity of the infrastructural relationship (Rose and Miller, 1992; O’Malley, 1996; Rose, 1996; Henman, 2004). Thus, control is not simply about realising political stability but is also about promoting individual responsibility in infrastructure interactions, with the state exercising its power to influence the behaviour of agents within the context of its mandate (O'Malley, 1996; Rose, 1996). This involves users understanding the social goods aspect of beneficial infrastructure usage and what runs contrary to this in their everyday interactions within the system (Rose and Miller, 1992).

As an extension of this control function of NIS, Rodgers and O'Neill (2012) refer to the concept of infrastructural violence whereby infrastructures can be used by state and non-state agents to promote violence and inflict suffering. The literature on structural violence (see Farmer, 2004) suggests infrastructures can act as mechanisms for the systemic assertion of violence by those in control of infrastructure usage. This can occur through the use of or, more so, through the absence of infrastructure. Thus, at the confluence of territorial control and integration, control can be asserted by the absence of infrastructure which intentionally excludes users. In the latter case, suffering comes not through military control but through the absence of infrastructure which provides core social services. In such contexts, infrastructure preserves internal security through the absence, degradation or denial of access to infrastructure. This can 
intentionally isolate social groups and act as a means of inoculating the rest of the social system from perceived or actual harm from specific segments of the population. Conversely, such exclusion from infrastructure systems can create the conditions for internal security threats.

\section{Integration}

The integrative aspect of NIS lies in their ability to generate the spatial and temporal compression that promotes territorial economic, social and political cohesion (Edwards, 2003; Munnel, 1992; Rietveld, 1995). It has long been argued (for example, Hartshorne, 1950) that the role of the state is to bind together assorted social and territorial segments into an effective whole through a mix of vertical (for social groups) and horizontal (for territorial groups) processes (Martin and Rogers, 1995). In policy terms, the infrastructural mandate as a means of territorial integration involves the convergence of a range of policies such as social and regional policies that facilitates the emergence of a scalable NIS that allows all parts of a state's territorial domain to access essential infrastructures. Implicit in this strategy is Lefebvre's notion of abstract space which stresses that the role of the state is to create territorial homogeneity through the enabling of social, political and economic relations (Brenner, 1999a, 1999b).

Conventionally, integration themes reflected a 'welfarist' approach (Gramlich, 1994) to NIS development as encapsulated within a 'modern infrastructural ideal' (Graham and Marvin, 2001). However, there has been a shift towards a more market-driven NIS that favours growth over inclusion (Rose and Miller, 1992; Estache and Fay, 2007; Majone, 1997). The result has been a splintering of the NIS where infrastructure provision varies according to user requirements rather than being guided by principles of universality (Graham and Marvin, 2001). The resultant variation in quality and quantity of infrastructure across socio-economic strata creates the risk of power asymmetries across a territory (Massey, 2005) with the potential to inhibit territoriality (Mann, 1997; Offner, 1999). This latter point indicates that infrastructure provision is a unifying force for social solidarity with this cohesion based on the notion of the aforementioned infrastructural ideal. There is a danger that erosion of the integrative element of the NIS in circumstances in which there is a large private-sector involvement in the NIS can undermine consensus within it and result in fragmentation as a result of the de facto withdrawal of public goods (Willke, 1992). 


\section{Security}

NIS have a strong external dimension whereby they interact and interconnect with other NIS (Held et al., 1999; Scholte, 2005). At this interface, security (defined here as external threats to the military, political, societal, environmental and economic security of the state that can be mobilised through the interaction between and within NIS Williams, 2003) emerges as a strategic challenge to state territoriality. States have had to adapt NIS to economic, technological and environmental changes (either singularly or in combination) that have rendered these complex NIS vulnerable to man-made and naturally occurring events and processes. These events/processes create the potential to disrupt infrastructural relations and thereby undermine NIS functioning and compromise the state's infrastructural mandate (Rinaldi et al., 2001). Security is core to the legitimacy of the state. In its absence, citizens potentially face a multitude of threats and dangers arising from the way complexity and global change have created uncertainty over the stability and sustenance of relational infrastructure systems (Moteff, 2012).

The rise of the polycentric NIS underlines the above point that the state will sustain a strong legitimisation function, especially where such infrastructures are deemed critical to state territoriality (Turner, 2017). In most cases, the state will tightly regulate to ensure its interests are met with the option of expropriation should non-state providers violate its mandate (Organisation for Economic Co-operation and Development, 2008). Such concerns have proved especially relevant in border and gateway infrastructures where externally sourced flows are filtered or subject to illicit flows. These 'supra-structures' are those structures that are intentionally visible (rather than embedded within socio-economic structures as mentioned above) for the purposes of conveying the power of the state to control and assert its territoriality (Larkin, 2013). For example, the rhetoric over the building of a wall between the US and Mexico is about demonstrating state territoriality over rights of access. It is a shifting narrative: states are conventionally focused on infrastructures that facilitate flows, but the wall is about more effective monitoring and channelling of flows and increasing transaction costs for flows that occur across this border (see Chapter 4). The US border wall debate reflects a new dimension of critical infrastructure systems whereby nativism asserts influence over the form and shape of the NIS. The narrative on external-facing threats and how they impact on infrastructure systems (via concerns on state security) extrapolates the theme identified by Graham (2010) regarding infrastructural warfare. This confirms that states need infrastructure to protect themselves from harmful external 
flows that result from the intentional targeting of infrastructural networks which can have a system-wide impact, resulting in suffering.

\section{Growth/development}

Contemporary policy narratives are heavily shaped by the nexus of growth and infrastructure as informed by the logic of endogenous growth theory (Romer, 1994). This reflects a Foucaultian perspective that the core welfare focus of the state is to generate economic growth. Infrastructure plays a major role in organising and rationalising resources within a state by fostering communication and exchange and by shaping the state's economic geography (Canning and Pedroni, 2004; Aschauer, 1989; Easterly and Rebelo, 1993; Canning et al., 1994; Sanchez-Robles, 1998).

These themes have been raised in debates surrounding the competition state and how the NIS is a platform for the global positioning of the state (Romp and de Hann, 2007; Röller and Waverman, 2001). In this context, the role of the NIS is to enable markets to work efficiently by facilitating and stimulating flows, both within and external to the state (Palan et al., 1996). By implication, this challenges cohesion as the state is incentivised to develop and push users towards those parts of the NIS that have a positive impact on economic performance. Pressure from the competition state should, in theory, lead states to develop those systems that reflect and stimulate traffic flows both within the states and between states (Agénor and Moreno-Dodson, 2006).

The prevailing narrative on infrastructure in international economic systems reflects a desire to militate against the impact of the absence of and/or deterioration of infrastructure upon transaction costs and thus on interactions between states (Glykou and Pitelis, 2011). The logic is that investing in infrastructure decreases the cost of undertaking trade, thereby increasing the potential for trade. This narrative on economic growth/development reflects that the function of the NIS - especially within the logic of the competition state - is a key component of the state's export system. The NIS is the means through which commodities and fully and part-finished products are moved to and through the state's gateways (i.e. through points in the NIS where flows are deterritorialised and reterritorialised). These gateways are shaped by the economic need to interact with the global system where the NIS is seen as a catalyst of value-creating relationships. 
Expressed within the terms of the infrastructural mandate (and its intimacy with state territoriality), the creation of RIS starts to emerge as strategic acts by states to reinforce and/or secure one or more of the core facets of the infrastructural mandate. Implicit within such an approach is that the state cannot capture all the relations necessary to secure its mandate within its own demarcated space and that there is a degree of extra-territoriality embedded within the NIS (Painter, 2010). This theme of extra-territoriality within the infrastructural mandate is a subject which will be returned to later as the clear logic underpinning much of the analysis within the volume is that the state feels compelled to regionalise the NIS as a means of fulfilling its infrastructural mandate. However, before this is addressed, it is necessary to address the contextual changes placed on NIS by the forces of regionalism. It is through understanding such processes that the logic of regional infrastructuring emerges.

\section{THE RISE OF REGIONALISM}

Regionalism is defined by Bhagwati (1992) as a process of intergovernmental collaboration between multiple states largely motivated by the processes of economic integration driven initially by preferential trade agreements between partners (Wei and Frankel, 1998). The nature of the region (as utilised within this work) is developed at the level of interstate agreement where the focus (due to the nature of infrastructure) is on trans-national formations based on contiguous or semi-contiguous space (that is, where states are in close geographic proximity but do not necessarily share a border) (Baldwin, 2006). Whilst recognising the extensive literature based on regionalism and regionalisation (for a comprehensive introduction see Ravenhill, 2014), it is not the intention here to review these themes extensively; as such, the main political and economic motivations for regionalism are summarised in Table 1.1. The main focus of this section is merely to understand regionalism as a process that is shaping the contextual drivers behind the evolution of NIS and RIS.

Palan et al. (1996) view the trend towards regionalism through the lens of the competition state and suggest that it is motivated by a belief that state-based territoriality is not always the most effective method of enabling the state to attain its core objectives. As European integration, for example, has advanced, states have come to see their collective economic power as an effective counterweight to the hegemonic economic power of the US and, increasingly, of China. The European states 


\section{Table 1.1 Drivers of regionalism}

\begin{tabular}{lc}
\hline Political drivers & Economic drivers \\
\hline - Economic co-operation facilitates & $\begin{array}{c}\text { - Offers more scope for protection than } \\
\text { multilateralism }\end{array}$ \\
$\begin{array}{l}\text { security } \\
\text { Builds confidence between }\end{array}$ & $\begin{array}{c}\text { Promotes and secures economic reform } \\
\text { participating states }\end{array}$ \\
$\begin{array}{l}\text { - Exposes inefficient domestic producers } \\
\text { to competition and so promotes reform }\end{array}$ \\
- Protects against external threats & - Offers scope for deeper integration \\
- Addresses non-traditional security & than available at the global level \\
threats such as environmentalism & - Enables agreement on difficult issues \\
- Operates as a means of exercising & - Leads to larger markets and higher \\
power within the international system & levels of foreign direct investment \\
(especially for smaller and/or less & \\
developed states) & \\
- Embeds and secures political reform & \\
- Pacifies internal political forces & \\
- Simplifies negotiation and & \\
implementation of international & \\
agreements & \\
\hline
\end{tabular}

seek to use the collective power of integrated internal regional markets as leverage to enhance their economic and political power. States look at the experience of the rise of these hegemonic powers and of their ability to harness scale as a means of promoting economic growth and development. The academic literature identifies three broad characteristics that have generated momentum towards regionalism within the global economy. First, regionalism is seen as an extension of the multilateral trading system. Second, the trend towards regional integration is viewed as a political strategy to enhance and secure the competitive position of the constituent states. Third, regionalism is regarded as a structural response to problems generated by economic globalisation.

According to neo-classical logic, the move towards scale is created by economic forces and not by simple government promotion of regional champions. In strategic terms, fragmentation of industrial structures within regions renders these locations at a competitive disadvantage. According to Porter (1990), scale emerges through competition: it is the intensity of competition that drives regional competitiveness and consolidation. In turn, this push to scale - it is argued - will improve the terms of trade and act as a strong magnet for investment. Realist interpretations of regionalism treat it as being politically motivated by these regional powers as a means of enhancing their bargaining positions in the global economic and political system (Gilpin and Gilpin, 2000). In this view, 
states combine their collective interests through the sharing of sovereignty to further advance their combined interests. The final perceived driver - and one that has been advanced by many neo-liberals - is that the move towards regionalism is driven by the power of business interests to encourage states to merge markets to generate greater efficiency through reducing transaction costs.

The pursuit of economies of scale has played a powerful factor in legitimising the process of political integration and larger economic units, even if the gains from such measures are not always immediately obvious. Palan et al. (1996) criticise realist views which treat both the state and, as a consequence, the region as a 'black box' without any serious attempt to explain how such positions emerge. As such, they argue a more eclectic approach has to be taken to help understand the regionalisation process where the main drivers interact to push the process forward. However, regionalism has to be seen as more than a simple strategy for state competitiveness. It also creates supporting institutional frameworks to support the process, it drives state restructuring and it is becoming a key tool of governance within the global economic system. In this context, Hettne (1997) argues that the move towards regionalism reflects a neo-mercantilist position. Regionalism is a set of policies rather than a policy based on the single theme of trade. Regionalism is not based on the notion of the closed economy but on the need of states to position themselves within the global system and acts as a source of stability within it.

Since the 1990s, there has been an increasing theme within the literature about what has become known as 'new-regionalism' (Ethier, 1998; Schirm, 2002). Whereas 'old regionalism' emerged from the impact of interstate nationalism and the legacy of the Second World War and spread from Europe to other continents throughout the 1960s and 1970s, new regionalism developed from the liberalising trends associated with the European single market initiative, the influence of which also spread across other continents (Söderbaum, 2003). In reality, the newness of this process is more imagined than real as new regionalism built on foundations created by more traditional forms of regional integration (Ethier, 1998; Hettne, 1999). These new forms of regionalism do, however, differ from conventional forms as they are more geographically extensive and have a stronger degree of embeddedness within the broader international system. The newer forms of regionalism are also often vastly different to conventional forms, especially regarding structure and form which also extend beyond the traditional focus on preferential trade and security. Arguably, the main shift is in the differing context in which such moves have occurred, notably within an environment shaped by the 
hegemonic influence of neo-liberal globalisation. This shift was also reinforced by the end of the Cold War which opened up new forms of regionalism, especially in eastern Europe and Asia. In many cases, the shift towards regionalism during the 1990s reflected a desire to enhance competitive positioning through deepening integration. These neo-liberal and political drivers were also compounded by:

- difficulties in reaching multilateral agreements resulting in the 'second best' option of regional agreements;

- contagion effects whereby the growth of regionalism in one area spreads to other regions of the global economy;

- the changing US position on regional integration where such agreements aid its political objectives;

- the rendering of regional trade agreements as harmonious with the constituent state requirements under the World Trade Organization;

- advances in trade theory, especially in strategic trade theory which stresses that protectionism can be rationalised through the realisation of economies of scale which, in turn, can enhance competition in global markets where scale is a requisite (Krugman, 1986);

- the geographic dispersion across regions of industry value chains, especially as many multinational corporations are focused on a limited number of regions (Rugman, 2005).

A major focus for political economists is the dynamics of regionalism (Walz, 2012); that is, the forces generated by the stimulation of regionalism that can drive a process of inexorable deepening. Most regional agreements are shallow intergovernmental agreements based on trade and do not require the establishment of supporting regional institutions as any disputes can be settled by intergovernmental negotiation (Schiff and Winters, 1998; World Trade Organization, 2016). However, where integration deepens, the rationale for a separate set of institutions at the regional level strengthens. This has had its most evident expression in the case of the European Union, the experience of which has often formed the basis for much of the theoretical developments in regionalism (Wallace, 1990). This regional dynamic has arguably had its most effective expression within the concept of neo-functionalist 'spillover' where co-operation in one area increases pressures to co-operate in other areas (for example, Gehring, 1996). This in-built momentum within the process is sustained by an awareness of the costs of divergent, uncoordinated policies. The process can also be reinforced by the opportunistic activity of regional institutions. However, state primacy and the sustenance of intergovernmentalism openly questions this 'internal' dynamic 
approach (Moravcsik, 1993). Authors from the intergovernmental approach see the delegation of decision making to supranational institutions as a rational, self-interested act in the assertion of national economic interests. Whilst such debates are beyond the scope of this work, the forces that drive regional infrastructuring will be a pivotal factor in explaining how RIS emerge and evolve.

According to Hettne (1997), trans-national regionalism can involve the expression of a regional identity similar to that of nationalism. As such, regionalism (especially the new regionalism) can be seen as an extension of nationalism. Thus, although many of the narratives in the literature are focused on trade, there is a clear underpinning that regionalism has clear political dimensions. This political dimension can be shaped by local forces bubbling up from below or by hegemonic power seeking to stabilise the international system. In practice, new regionalism tends to be characterised by the former. Furthermore, Hettne (1997) argues that regionalism is of increasing complexity and, as the process deepens, a stronger sense of territoriality emerges out of closer organised co-operation, the emergence of regional civil society and of a region as a unit with a stronger expression of regional territoriality. The logic - in terms of territoriality and of infrastructuring - is that in a deeper form of regionalisation, national systems become subsumed into a regional network of networks. Such hyper-regionalism represents an extreme position as states continue to be dominant. Nonetheless, regionalisation does imply higher degrees of homogeneity across cultural, economic, security and political spheres.

\section{INFRASTRUCTURING AND THE REGIONAL IMPERATIVE}

Whilst it is argued here that states are the primary forces driving territorial infrastructure, the rescaling of relations across borders highlights a need for the state to adapt to the shifting context within which NIS operate. The steady erosion of the exclusivity of state territoriality as the only meaningful form of territory has been noted in the work of authors such as Taylor (1994) and Agnew (1994) who, despite approaching the subject from different disciplinary perspectives, both acknowledge that, although the state remains a primary force in the international system, territoriality cannot be neatly confined within the borders of the state. The state has become what Taylor $(1994,1995)$ has termed a 'leaking, bordered power container' whose power to control all activity within its borders is being diluted by a mix of economic, social, political 
and environmental processes. Agnew (2005) argues that the focus on the state as the unit of territoriality tends to be both ahistorical and obscures processes occurring on other scales (in this case, regional). In terms of the analytical framework deployed here, the suggestion is that the state's infrastructural mandate cannot be realised solely from infrastructure located within the borders of the state and that, as a consequence, it will need to capture externally sourced flows to enable its territoriality. This places an emphasis on the state to adopt strategies which reflect extra-territorial components and influences. It can achieve this by integrating external dimensions into the NIS or by becoming involved in extra-territorial infrastructure systems.

Regionalism within NIS implies that there are segments of the infrastructural mandate that, if not externally determined, are at least influenced by external forces. These extra-territorial forces do not challenge state primacy but merely reflect that it is one force amongst many shaping the attainment of the state's infrastructural mandate. According to Agnew (1994) and reflecting Mann's notion of infrastructural power (Mann, 1984), the ability of the state to assert control depends not only on its ability to penetrate its territory but also to offer public services that sustain the legitimacy of this function over these systems. In an international system of flows, it cannot be ruled out that powers other than the state can penetrate civil society. As Brenner (1999b) argues, territoriality is historically specific and, as a result, infrastructures are under a constant process of updating and reconfiguration as the demands placed on them alter. Infrastructural relations can no longer be confined within the borders of the state (Glassman, 1999; Painter, 2010): increasingly, infrastructural relations are being extended, especially where local processes are integrated into global value chains in which actors selectively participate. Consequently, Painter (2010) argues that territory can be understood to be the result of both 'networked social-technical practices' and the network of relations which, according to Sassen (2013), means that many infrastructures can no longer be conceptualised as purely national as they function across a larger operational space. Keating (2013) suggests that whilst this does not render states obsolete (as proposed within more extreme deterritorialisation theses), they are not necessarily cornerstones of the system.

According to Brenner (1999a), the emergence of RIS involves NIS adapting to the forces of regionalisation as the freedom of flows embedded within such processes has to be enabled and supported through the production, reconfiguration, redifferentiation and transformation of infrastructure to facilitate this expanded and augmented movement. Conventional analysis has tended to treat state territoriality (as expressed 
within its sovereign rights) as a polar opposite to global processes where the rise of the latter erodes the territoriality of the former (Ohmae, 1999). However, it has been increasingly recognised that such a 'zero sum' perspective is misleading (for example, Weiss, 2005) as the relationship between the state and the market is increasingly one of mutual dependence. The neo-Weberian state pursues a number of objectives to ensure its survival and prosperity: tapping into global flows is an increasingly powerful enabler of this strategy (O'Tuathail et al., 1998). Much of the literature has emphasised the role of economic interactions as a major adaptive force (Johnson and Turner, 1997, 2007). However, it is becoming increasingly apparent that these adaptive tensions are also evident in other aspects of the state's infrastructural mandate, notably in relation to political/economic security and integration (Buzan and Waever, 2003).

A related theme in the drive towards RIS is the extent to which they emerge through the processes of old or new regionalism or a mix of both. Old regionalism is clearly aligned with the state-based approach in which infrastructuring is an intentional strategy deployed to reflect the shifting context of NIS (Macleod, 1999). The logic of new regionalism suggests that these RIS are generated by forces bubbling up from below that necessitate a stronger degree of integration. As such, these infrastructures are less about state territoriality and more about enabling cross-border interaction. In this vein, RIS are more the product of outward-looking notions of new regionalism in which integrating NIS is a means of dealing with increasing interdependence. Hettne and Söderbaum (1998) refer to the idea that intergovernmental co-operation based on individual states acting in concert for mutual benefit has been a common form of agreement in areas such as infrastructure. Such arrangements can be formal but also very loose. However, if RIS are seen as reactive, then other forms of integration come into play as drivers in the process. Nye (1997) refers to state-promoted regional integration whereby the respective economies become intertwined with minimal loss of sovereignty. It is evident that such processes necessitate the fuller integration of NIS to facilitate this process. As such, the move towards regionalism within infrastructure systems reflects an adaptive response by states to the external pressures upon them (Weiss, 1998). In short, states interconnect infrastructures to form complex regional systems. Glassman (1999) takes issue with the conclusions of Weiss (2005) by arguing that these systems do not emerge so much through a process of adaptation but through the internationalisation of the state which he defines as the need for the state to facilitate capital accumulation for investors. This can be loosely related to themes engendered in narratives informed by the logic of the competition state. 
As stated above, RIS are treated not as separate systems existing above the level of the state but as a network of NIS across contiguous or semi-contiguous space (that is, in close proximity). As such, the core research issue is why states - in pursuing their own interests - seek to integrate into RIS. The approach here reflects basic realist approaches to the study of IPE as there is evidently no body above the state actively involved in infrastructuring (a point explored in later chapters) and, whilst there are an increasing number of private and other non-state infrastructures, these systems remain commercially and politically dependent on the territorial control exercised by the state. Thus, whilst there is an evident case that infrastructural relations can no longer be solely captured within the confines of the borders of the state (for a review, see Keating, 2013), they still depend on the state-based system, either as a source, destination or for transit. Murphy (2013) suggests that states have been unwilling to cede territoriality strategies to supranational bodies. As such, RIS emerge out of state territorial needs. In a regional system of flows, the state is the body that has the desire/need to control the intensity of the deterritorialisation and reterritorialisation of crossborder flows. Addressing the extra-territorial determinant of the infrastructural mandate is central to its realisation. At best, supranationality focuses on promoting intergovernmental co-ordination to stimulate the development of 'missing links' between NIS rather than on stimulating territorial systems (De, 2006).

Given state primacy in the development of infrastructure systems, it is evident that RIS are most likely to emerge out of intergovernmentalism (Börzel, 2010). The realist tradition stresses that RIS emerge out of the need of the state to protect and secure its territorial interests (Puchala, 1999; Guzzini, 2013) and that integration will be limited to a few areas that do not impinge of state territoriality (Söderbaum, 2012). Consequently, intergovernmentalism implies that RIS emerge out of the needs of states to recognise (regional) extra-territoriality within its infrastructure system by co-operating with other states that are experiencing similar trends. In such cases, integration is a recognition that one state's NIS is dependent on another and that - in the absence of a regional infrastructuring authority - states need to co-operate for mutual advantage. Finally, there is a pattern whereby powerful states undertake extra-territorial infrastructuring as a means of enabling its own mandate (Börzel, 2016). Part of the rationale for the state-centred approach to regional infrastructure is that there is little evidence of regional territoriality, of a regional infrastructuring capability and of any delegation (or desire to delegate) of power to these ends. In these circumstances, a 
major theme of this book is that RIS are an extension of state-based territoriality (Schneider and Jäger, 2003).

In view of the above narratives, RIS emerge as a rational act by states as a means of securing or reinforcing the infrastructural mandate, notably in terms of growth and security (Hettne and Inotai, 1994). In developing an analysis of RIS, this volume does not offer a single definition of a RIS but focuses on two main forms of RIS. These are:

- The interworking, interoperation and interconnection of separate national systems across a contiguous space to the extent that they create a virtual regional system of national systems. This recognises that the respective NIS are the core building blocks of the system in which existing national systems begin to operate as a network of networks by investing in capacity at key pinch points (notably via investment in national gateways) and by aligning soft infrastructure across systems in areas such as standards and trade facilitation to enhance flows of goods, services and factors of production across internal regional borders (Niskanen, 1991).

- A single infrastructure that operates across multiple contiguous territories where such territories are the source, destination and/or place of transit for trans-national flows. These infrastructures are explicitly designed to enable trans-national flows rather than simply emerging from the interconnection of existing systems and tend to be limited to the energy sector where cost factors drive this mode of transmission. In a state-based system, such trans-national systems remain heavily dependent on state legitimisation. As such, although infrastructural relations exist beyond state borders, they continue to be dependent on states, either for transit or de/reterritorialisation.

The treatment here is to align regional systems with formal processes to push economic integration within a regional grouping. RIS are positioned as state-based systems as there is no regional grouping that possesses an infrastructural mandate and, as such, infrastructure emerges out of interstate co-operation. Whilst development agencies that co-finance such systems clearly exist (see Chapters 3 and 4), they are largely incidental to state-based sources and there is no body above the level of the state that makes any meaningful contribution to the development of RIS. In this sense, regionalism represents tension within NIS to which states have to adapt. In response, it is apparent that these tensions emerge through a number of channels, including one or more of the following: 
- Integration through formal processes of integration: the shift towards RIS occurs as a reaction to increased cross-border flows that have been directly stimulated by formal economic integration agreements between states. These find direct parallels in the processes that form and shape the emergence of RIS that emerge out of new regionalism. This formality arises from state-based agreements to lower barriers to interstate flows. This is in contrast to informal processes that are largely shaped by market-driven processes whereby RIS emerge out of market-driven flows. However, it is evident that the differentiation between these two drivers (especially with regards to regional infrastructuring) is more apparent than real as formal agreements can create more informal pressures by facilitating trans-national markets that require supporting infrastructure.

- Integration through bilateral agreement: this driver is shaped by agreement between two states to interconnect their respective NIS. Whilst they are usually formal agreements between states, they frequently exist outside (or alongside) more formal regional economic integration agreements in which such states participate. The agreements tend to occur when the states involved share a common border across contiguous space and/or where one of the states involved is not part of a more far-reaching formal integration process.

- Global/regional hegemonic pressures: one of the main roles of a hegemon within the regional/global system is to preserve and/or enhance the stability of the international system. The hegemon can do this via extra-territorial infrastructuring whereby it becomes involved in another state's infrastructure in a location beyond its borders. Evidently, such infrastructuring finds international legitimacy in those cases where the state involved is located at a key 'pinch point' in the global economic system and where that state does not possess the necessary capabilities to develop, secure or enhance this key infrastructure. Furthermore, the hegemon can become involved in extra-territorial infrastructuring as a means of generating the public good of international security. This is especially relevant with regards to the exercise of maritime power. Finally, the hegemon - on either a global or a regional level - can engage in extra-territorial infrastructuring to support or enhance its own infrastructural mandate. This is evident where it develops regional infrastructure in contiguous space to enhance the integration of its own peripheral regions into the global economy or to facilitate access to raw materials. Thus, the hegemon's involvement 
in RIS does not necessitate geographic proximity to the state where it is active.

- Multilateral agreement outside formal agreements: these are multilateral agreements between more than two states which lie outside formal economic integration agreements. The status of such agreements outside formal arrangements can be because one or more of the states involved do not participate in such arrangements. These agreements are most common within the energy sector and can involve multiple states apart from those which represent the source and ultimate destination of the flows. In this circumstance, thirdparty states often become involved because of the requirement for transit rights which are usually granted in return for transit fees.

The list of RIS types discussed above is by no means definitive but it does highlight that there can be a disconnect between the emergence of RIS and the process of formal regionalism. Formal regionalism suggests conventional spillover in the process of RIS formation. However, states infrastructure for more reasons than simply reactive pressures to regional flows, notably for security, etc. The diversity of drivers in the formation of RIS is reflected in chapters where the relative importance of formal and informal integration drivers of RIS are addressed.

\section{CONCLUSION}

This chapter introduces the main concepts and issues involved in the creation and development of RIS. In understanding the nature of infrastructure, it is important to consider elements of infrastructure systems beyond their physical components. As such, there is an increased focus within the literature on soft infrastructure which is central to enabling the operation and integration of infrastructure systems. In focusing on state primacy within the development of such systems, it is necessary to consider infrastructuring as a component of state strategy in which states infrastructure to preserve their position both within - and where needed beyond their territory. This is reflected in the infrastructural mandate which identifies those key characteristics which a state requires of an infrastructure system to enable it to fulfil its core functions. The focus has been on regionalism as an adaptive driver of change within infrastructure systems. The argument is that the process of regionalism (both formal and informal) represents an adaptive tension on NIS to which they are expected. This adaptive tension is not merely about scaling up the system but is also about interconnecting national systems as a means of 
enabling, supporting or enhancing the infrastructural mandate. As such, RIS represent a rational act as states seek to adapt to the state's shifting context. Moreover, the formation of infrastructure within the contemporary system is best seen as a state-based system. Therefore, regionalism is not simply a scaling up of national systems but also the establishment of dedicated systems and regional infrastructure. The key issues to address are why states look to scale up domestic systems to interconnect with those of other states and how such measures fit with a state's infrastructural mandate. The final section brings regionalism and infrastructuring together to explore the trend towards regional infrastructuring. The themes within the section, notably regarding the patterns and processes shaping RIS, are returned to throughout the following chapters.

\section{REFERENCES}

Agénor, P. and Moreno-Dodson, B. (2006) Public infrastructure and growth: new channels and policy implications, World Bank: https://openknowledge.world bank.org/, accessed 4 May 2016.

Agnew, J. (1994) 'The territorial trap: the geographical assumptions of international relations theory', Review of International Political Economy, 1(1), 53-80.

Agnew, J. (2005) 'Sovereignty regimes: territoriality and state authority in contemporary world politics', Annals of the Association of American Geographers, 95(2), 437-61.

Aschauer, D. (1989) 'Is public expenditure productive?' Journal of Monetary Economics, 23(2), 177-200.

Auster, R. and Silver, M. (1979) The state as a firm: economic forces in political development, London: Springer Science and Business Media.

Baldwin, R. (2006) 'Multilateralising regionalism: spaghetti bowls as building blocs on the path to global free trade', World Economy, 29(11), 1451-518.

Bhagwati, J. (1992) 'Regionalism versus multilateralism', World Economy, 15(5), 535-56.

Börzel, T. (2010) 'European governance: negotiation and competition in the shadow of hierarchy', Journal of Common Market Studies, 48(2), 191-219.

Börzel, T. (2016) 'Theorizing regionalism: cooperation, integration, and governance', in Börzel, T. and Risse, T. (eds), The Oxford Handbook of Comparative Regionalism, Oxford: Oxford University Press.

Braithwaite, J. and Drahos, P. (2000) Global business regulation, Cambridge: Cambridge University Press.

Brenner, N. (1999a) 'Globalisation as reterritorialisation: the re-scaling of urban governance in the European Union', Urban Studies, 36(3), 431-51.

Brenner, N. (1999b) 'Beyond state-centrism? Space, territoriality, and geographical scale in globalization studies', Theory and Society, 28(1), 39-78.

Brenner, N. and Elden, S. (2009) 'Henri Lefebvre on state, space and territory', International Political Sociology, 3, 353-73. 
Brown, K. A. (2006) Critical path: a brief history of critical infrastructure protection in the United States, Fairfax, VA: Spectrum Publishing Group.

Buzan, B. and Waever, O. (2003) Regions and powers: the structure of international security, Cambridge: Cambridge University Press.

Canning, D. and Pedroni, P. (2004) The effect of infrastructure on long run economic growth, mimeo, Harvard University.

Canning, D., Fay, M. and Perotti, R. (1994) 'Infrastructure and growth', in Baldassarri, M., Paganetto, L. and Phelps, E. (eds), International differences in growth rates, New York: St. Martin's Press, 285-310.

De, P. (2006) 'Trade, infrastructure and transaction costs: the imperatives for Asian economic cooperation', Journal of Economic Integration, 21(4), 708-35.

Easterly, W. and Rebelo, S. (1993) 'Fiscal policy and economic growth: an empirical investigation', Journal of Monetary Economics, 32(3), 417-58.

Edwards, P. (2003) 'Infrastructure and modernity: force, time, and social organization in the history of sociotechnical systems', in Misa, T., Brey, P. and Feenberg, A. (eds), Modernity and technology, Cambridge, MA: MIT Press, $185-225$.

Edwards, P., Bowker, G., Jackson, S. and Williams, R. (2009) 'Introduction: an agenda for infrastructure studies', Journal of the Association for Information Systems, 10, Special Issue, 365-74.

Elden, S. (2010) 'Land, terrain, territory', Progress in Human Geography, 34(6), 799-817.

Elden, S. (2013) 'Secure the volume: vertical geopolitics and the depth of power', Political Geography, 34, May, 35-51.

Eriksen, S. (2011) "State failure" in theory and practice: the idea of the state and the contradictions of state formation', Review of International Studies, 37(1), 229-47.

Estache, A. and Fay, M. (2007) Current debates on infrastructure policy, World Bank, policy review working paper 4110: http://documents.worldbank.org/ curated/en/423171468315830676/pdf/wps4410.pdf, accessed 5 March 2016.

Ethier, W. (1998) 'The new regionalism', Economic Journal, 108(449), 1149-61.

Farmer, P. (2004) 'An anthropology of structural violence', Current Anthropology, 45(3): 305-25.

Frischmann, B. (2012) Infrastructure: the social value of shared resources, Oxford: Oxford University Press.

Gehring, T. (1996) 'Integrating integration theory: neo-functionalism and international regimes', Global Society: Journal of Interdisciplinary International Relations, 10(3), 225-53.

Gilpin, R. and Gilpin, J. (2000) The challenge of global capitalism: the world economy in the 21st century, Princeton, NJ: Princeton University Press.

Glassman, J. (1999) 'State power beyond the territorial trap: the internationalization of the state', Political Geography, 18(6), 669-96.

Glykou, I. and Pitelis, C. (2011) 'On the political economy of the state, the public-private nexus and industrial policy', Policy Studies, 32(4), 461-78.

Graham, S. (ed.) (2010) Disrupted cities: when infrastructure fails, London: Routledge.

Graham, S. and Marvin, S. (2001) Splintering urbanism: networked infrastructures, technological mobilities and the urban condition, London: Routledge. 
Gramlich, E. (1994) 'Infrastructure investment: a review essay', Journal of Economic Literature, 32(3), 1176-96.

Guzzini, S. (2013) Realism in international relations and international political economy: the continuing story of a death foretold, London: Routledge.

Hartshorne, R. (1950) 'The functional approach in political geography', Annals of the Association of American Geographers, 40(2), 95-130.

Held, D., McGrew, A., Goldblatt, D. and Perraton, J. (1999) Global transformations, politics, economics and culture, Cambridge: Polity Press.

Henman, P. (2004). 'Targeted! Population segmentation, electronic surveillance and governing the unemployed in Australia', International Sociology, 19(2), 173-91.

Hettne, B. (1997) 'The double movement: global market versus regionalism', in Cox, R. (ed.), The new realism: perspectives on multilateralism and world order, Tokyo: United Nations University Press, 223-44.

Hettne, B. (1999) 'Globalization and the new regionalism: the second great transformation', in Sunkel, O., Inotai, A. and Hettne B. (eds), Globalism and the new regionalism, 1, 1-24.

Hettne, B. and Inotai, A. (1994) The new regionalism: implications for global development and international security, Helsinki: United Nations University World Institute for Development Economics Research.

Hettne, B. and Söderbaum, F. (1998) 'The new regionalism approach', Politeia, 17(3), 6-21.

Howe, C., Lockrem, J., Appel, H., Hackett, E., Boyer, D., Hall, R., ... and Ballestero, A. (2015) Paradoxical infrastructures: ruins, retrofit and risk. Science, Technology and Human Values: http://doi.org/10.1177/0162243 915620017, accessed 23 February 2017.

Hughes, T. (1983) Networks of power: electric supply systems in the US, England and Germany, 1880-1930, Baltimore, MD: Johns Hopkins University Press.

Hughes, T. (1987) 'The evolution of large technological systems', in Bijker, W., Hughes, T. and Pinch, T. (eds), The social construction of technological systems: new directions in the sociology and history of technology, Cambridge, MA: MIT Press, 51-82.

Hugill, P. (1995) World trade since 1431: geography, technology, and capitalism, Baltimore, MD, Johns Hopkins University Press.

Jackson, S., Edwards, P., Bowker, G. and Knobel, C. (2007) 'Understanding infrastructure: history, heuristics and cyber infrastructure policy, First Monday, 12(6).

Johnson, D. and Turner, C. (1997) Trans-European Networks: the political economy of integrating Europe's infrastructure, Basingstoke: Macmillan.

Johnson, D. and Turner, C. (2007) Strategy and policy for trans-European networks, Basingstoke: Palgrave Macmillan.

Johnson, D. and Turner, C. (2017) Global Infrastructure Systems, Cheltenham: Edward Elgar.

Kauffman, S. (1996) At home in the universe: the search for the laws of self-organization and complexity, Oxford: Oxford University Press.

Keating, M. (2013) Rescaling the European state: the making of territory and the rise of the meso, Oxford: Oxford University Press. 
Krüger, H. (1969) Marktwirtschaftliche Ordnung und öffentliche Vorhaltung der Verkehrswege, Hamburg: Metzner.

Krugman, P. (1986) Strategic trade policy and the new international economics, Boston, MA: MIT Press.

La Porte, T. (1996) 'High reliability organizations: unlikely, demanding and at risk', Journal of Contingencies and Crisis Management, 4(2), 60-71.

Larkin, B. (2013). The politics and poetics of infrastructure. Annual Review of Anthropology, 42, 327-43.

McKelvey, B. (2002) Managing coevolutionary dynamics, presented at the 18th EGOS Conference, Barcelona, Spain, 4-6 July.

MacLeod, G. (1999) 'New regionalism reconsidered: globalization and the remaking of political economic space', International Journal of Urban and Regional Research, 25(4), 804-29.

Majone, G. (1997) 'From the positive to the regulatory state: causes and consequences of changes in the mode of governance', Journal of Public Policy, 17(2), 139-67.

Mann, M. (1984) 'The autonomous power of the state: its origins, mechanisms and results', European Journal of Sociology, 25(2), 185-213.

Mann, M. (1997) 'Has globalization ended the rise and rise of the nation-state?' Review of International Political Economy, 4(3), 472-96.

Markard, J. (2011) 'Transformation of infrastructures: sector characteristics and implications for fundamental change', Journal of Infrastructure Systems, 17(3), 107-17.

Martin, P. and Rogers, C. (1995) 'Industrial location and public infrastructure', Journal of International Economics, 39(3), 335-51.

Massey, D. (2005) For Space, London: Sage.

Moran, M. (2003) The British regulatory state: high modernism and hyperinnovation, Oxford: Oxford University Press.

Moravcsik, A. (1993) 'Preferences and power in the European Community: a liberal inter-governmentalist approach', Journal of Common Market Studies, 31(4), 473-524.

Moteff, J. (2012) Critical infrastructure resilience: the evolution of policy and programs and issues for Congress, Washington, DC: Congressional Research Service.

Munnell, A. (1992) 'Policy watch: infrastructure investment and economic growth', Journal of Economic Perspectives, 6(4), 189-98.

Murphy, A. (2013) 'Territory's continuing allure', Annals of the Association of American Geographers, 103(5), 1212-26.

Neuman, M. (2006) 'Infiltrating infrastructures: on the nature of networked infrastructure', Journal of Urban Technology, 13(1), 3-31.

Niskanen, W. (1991) 'Soft infrastructure of a market economy', Cato Journal, 11(2), 233-44.

Nye, J. (1997) Peace in parts: integration and conflict in regional organization, Boston, MA: Little, Brown and Company.

Offner, J.-M. (1999) 'Are there such things as small networks?' in Coutard, O. (ed.), The governance of large technical systems, London: Routledge, 217-38.

Ohmae, K. (1999) The borderless world: power and strategy in the interlinked economy, revised edition, New York: HarperCollins. 
O’Malley, P. (1996) 'Risk and responsibility' in Barry, A., Osborne, T. and Rose, N. (eds), Foucault and political reason: liberalism, neo-liberalism and rationalities of government, Chicago, IL: University of Chicago Press, 189-207.

Organisation for Economic Co-operation and Development (2008) Protection of 'critical infrastructure' and the role of investment policies relating to national security: www.oecd.org/investment/investment-policy/40700392.pdf, accessed 3 May 2016.

O'Tuathail, G., Herod, A. and Roberts, S. (1998) 'Negotiating unruly problematics', in Herod, A., O'Tuathail, G. and Roberts, S. (eds), An unruly world? Globalization, governance and geography, London: Routledge, 1-24.

Painter, J. (2010) 'Rethinking territory', Antipode, 42(5), 1090-118.

Palan, R., Abbott, J. and Deans, P. (1996) State strategies in the global political economy, London: Burns and Oates.

Porter, M. (1990) The competitive advantage of nations, New York: Free Press.

Puchala, D. (1999) 'Institutionalism, intergovernmentalism and European integration: a review article', Journal of Common Market Studies, 37(2), 317-31.

Ravenhill, J. (2014) 'Regional trade agreements', in Ravenhill, J. (ed.), Global political economy, 4th edn, Oxford: Oxford University Press, 139-70.

Rietveld, P. (1995) 'Infrastructure and spatial economic development', Annals of Regional Science, 29(3), 117-19.

Rinaldi, S., Peerenboom, J. and Kelly, T. (2001) 'Identifying, understanding, and analyzing critical infrastructure interdependencies', Control Systems, IEEE, 21(6), 11-25.

Rodgers, D. and O'Neill, B. (2012) 'Infrastructural violence: introduction to the special issue', Ethnography, 13(4), 401-12.

Röller, L. and Waverman, L. (2001) 'Telecommunications infrastructure and economic development: a simultaneous approach', American Economic Review, 91(4), 909-23.

Romer, P. (1994) 'The origins of endogenous growth', Journal of Economic Perspectives, 8(1), 3-22.

Romp, W. and De Haan, J. (2007) 'Public capital and economic growth: a critical survey', Perspektiven der Wirtschaftspolitik, 8(S1), 6-52.

Rose, N. (1996) 'Governing "advanced liberal" democracies', in Barry, A., Osborne, T. and Rose, N. (eds), Foucault and political reason: liberalism, neo-liberalism and rationalities of government, 2nd edn, Chicago, IL: University of Chicago Press, 37-64.

Rose, N. and Miller, P. (1992) 'Political power beyond the state', British Journal of Sociology, 43(2), 173-205.

Rugman, A. (2005) The regional multinationals: MNEs and global strategic management, Cambridge: Cambridge University Press.

Sanchez-Robles, B. (1998) 'Infrastructure investment and growth: some empirical evidence', Contemporary Economic Policy, 16(1), 98-108.

Sassen, S. (2013) 'When territory deborders territoriality', Territory, Politics, Governance, 1(1), 21-45.

Schiff, M. and Winters, L. (1998) 'Dynamics and politics in regional integration arrangements: an introduction', World Bank Economic Review, 12(2), 177-95.

Schirm, S. (2002) Globalization and the new regionalism: global markets, domestic politics and regional cooperation, Cambridge: Polity. 
Schneider, V. and Jäger, A. (2003) 'The privatization of infrastructures in the theory of the state: an empirical overview and a discussion of competing theoretical explanations', in Wubben, E. and Hulsink, W. (eds), On creating competition and strategic restructuring: regulatory reform in public utilities, Cheltenham: Edward Elgar, 101-37.

Scholte, J. (2005) Globalization: a critical introduction, Basingstoke: Palgrave Macmillan.

Söderbaum, F. (2003) 'Introduction: theories of new regionalism', in Söderbaum, F. and Shaw, T. (eds), Theories of new regionalism, Basingstoke: Palgrave Macmillan, 1-21.

Söderbaum, F. (2012) 'Formal and Informal Regionalism', in Shaw, T., Grant, J. and Cornelissen, S. (eds), The Ashgate research companion to regionalisms, Aldershot: Ashgate, 51-67.

Starr, S. and Bowker, G. (1995) 'Work and infrastructure', Communications of the ACM, 38(9), 41.

Starr, S. and Bowker, G. (2006) 'How to infrastructure', in Lievrouw, L. and Livingstone, S. (eds), Handbook of new media: social shaping and social consequences of ICTs, London: Sage, 230-45.

Starr, S. and Ruhleder, K. (1996) 'Steps toward an ecology of infrastructure: design and access for large information spaces', Information Systems Research, 7(1), 111-34.

Stopford, J., Strange, S. and Henley, J. S. (1991) Rival states, rival firms: competition for world market shares, vol. 18, Cambridge: Cambridge University Press.

Strange, S. (1996) The retreat of the state: the diffusion of power in the world economy, Cambridge: Cambridge University Press.

Taylor, P. (1994) 'The state as container: territoriality in the modern worldsystem', Progress in Human Geography, 18(2), 151-62.

Taylor, P. (1995) 'Beyond containers: internationality, interstateness, interterritoriality', Progress in Human Geography, 19(1), 1-15.

Turner, C. (2017) 'The governance of polycentric national infrastructure systems: evidence from the UK National Infrastructure Plan', Environment and Planning C: Politics and Space, 36(3), 513-29.

Van der Vleuten, E. (2004) 'Infrastructures and societal change: a view from the large technical systems field', Technology Analysis and Strategic Management, 16(3), 395-414.

Wallace, W. (ed.) (1990) The dynamics of European integration, London: RIIA/Pinter.

Walz, U. (2012) Dynamics of regional integration, Munich: Springer Science and Business Media.

Wei, S. and Frankel, J. (1998) 'Open regionalism in a world of continental trade blocs', IMF Staff Papers, 45(3), 440-53.

Weiss, L. (1998) The myth of the powerless state: governing the economy in a global era, Ithaca, NY: Cornell University Press.

Weiss, L. (2005) 'The state-augmenting effects of globalisation', New Political Economy, 10(3), 345-53.

Williams, M. (2003) 'Words, images, enemies: securitization and international politics', International Studies Quarterly, 47(4), 511-31. 
Willke, H. (1992) Ironie des Staates, Berlin: Suhrkamp.

World Trade Organization (2016) Regional Trade Agreements Information System: http://rtais.wto.org/UI/PublicMaintainRTAHome.aspx, accessed 5 June 2016.

Zimmerman, R. (2001) 'Social implications of infrastructure network interactions', Journal of Urban Technology, 8(3), 97-119. 